\title{
A Critical Review of Heavy Metal Pollution and Its Effects in Bangladesh
}

\author{
Md. Simul Bhuyan*, Md. Shafiqul Islam \\ Institute of Marine Sciences and Fisheries, University of Chittagong, Chittagong, Bangladesh
}

Email address:

simulbhuyan@gmail.com (Md. S. Bhuyan)

${ }^{*}$ Corresponding author

To cite this article:

Md. Simul Bhuyan, Md. Shafiqul Islam. A Critical Review of Heavy Metal Pollution and Its Effects in Bangladesh. Science Journal of Energy Engineering. Vol. 5, No. 4, 2017, pp. 95-108. doi: 10.11648/j.sjee.20170504.13

Received: October 31, 2017; Accepted: February 10, 2017; Published: October 31, 2017

\begin{abstract}
Heavy metal, one of the most hazardous pollutant that can pose serious threat to human and environment. The concentrations of metals are increasing at an alarming rate due to boost of unplanned industrialization and urbanization. Though some metals are playing crucial role as micronutrients but the excessive amount exert negative impact at great extent. The existence of toxic heavy metals in the air, water and sediment can cause severe problems to all organisms because of their long persistence nature and bioaccumulation in the food chain. The present study reviews the various area of Bangladesh to make information on the sources of metal pollution, dissemination of metals in the environment and their possible effects on atmosphere, water, sediment, fishes and vegetables (plants).
\end{abstract}

Keywords: Industrialization, Heavy Metal, Pollution, Effect, Environment

\section{Introduction}

During last decade, rapid urbanization and industrialization have triggered some serious problems in environment. Heavy metals pollution is now a growing concern worldwide especially in developing countries [1] where rivers serve as dominant pathway for metals transport [2]. According to UNFPA [3], groundwater supplies most drinking water throughout the world, but many people use unsafe surface and groundwater sources. Though some people get access to water but not safe [4] because drinking water could be polluted with microorganisms [5], arsenic [6], polycyclic aromatic hydrocarbons (PAHs) [7], organic pollutants [8], nitrate and nitrite [9] and heavy metals [10]. Heavy metals are persistent, ubiquitous and nonbiodegradable in nature [11]. This characteristics of metals can pose chronic toxicity [12]. Considerable amount of metals accumulate in sediment and ultimately enter into the food chain through water, plants or leaching into groundwater. Heavy metals are responsible for brain damage or the reduction of mental processes [13] and central nervous function [14]. Moreover, it lower the energy levels [15], damage DNA [16] and alter the gene expression [17]. Skin
[18], muscle [19], blood composition [20], lungs [21], kidneys [22], liver [18], heart [23], and other vital organs for human and other living organisms are being damaged by acute metals infestation. Every sector are now under the heavy metal pollution and its effects also inescapable. Industrialization increases the specific family income and reform the social structure but the negative effects compelled environment to be extinct.

\section{Study Area}

Bangladesh is placed in South Asia, surrounded by India in the north, the Bay of Bengal in the east and west, while Myanmar surrounds it to the south. Bangladesh is the eighth most populated country in the world. The country is separated into seven administrative divisions, which are further subdivided into districts or zila. The geographical location: latitude and longitude for the country are $23.8511^{\circ} \mathrm{N}, 89.9250^{\circ} \mathrm{E}$ [24].

\section{Heavy Metal Pollution and Effects}

\subsection{Heavy Metal Pollution of River Water}

The Buriganga River known as biologically dead River 
[25] located in Dhaka, the heavily polluted river in Bangladesh. Fish, water and sediment are being contaminated by industrial wastes, municipal wastes and pesticides [26], [27]. The most common pollution is metal pollution. The heavy metal concentrations $(\mathrm{Pb}, \mathrm{Cr}, \mathrm{Mn}, \mathrm{Co}$, $\mathrm{Ni}, \mathrm{Cu}, \mathrm{Zn}, \mathrm{As}$, and $\mathrm{Cd}$ ) in water and sediment were very high and in most cases, exceeded permissible limits recommended by the Bangladesh government and other international organizations [26]. According to Ahmed et al. [27] and Das et al. [28] the concentrations of some heavy metals in water, sediment and fishes exceeded the recommended value. Sikder et al. [29] mentioned that the concentrations of $\mathrm{Al}$ and $\mathrm{Mn}$ surpassed the limit set by WHO [30] and the concentrations of $\mathrm{Fe}, \mathrm{Cu}, \mathrm{Zn}, \mathrm{Cd}$ and $\mathrm{Pb}$ found to be below the approved limit. Saha and Hossain [31] reported that the concentrations of $\mathrm{Pb}, \mathrm{Cu}$, and $\mathrm{Zn}$ were above the EPA guideline for heavily polluted sediment and the amount of $\mathrm{Cd}$ and $\mathrm{Cr}$ are fall in the criteria of moderately to highly polluted range. Mohiuddin et al. [25] found the concentrations of $\mathrm{Cr}, \mathrm{Pb}, \mathrm{Cd}, \mathrm{Zn}, \mathrm{Cu}, \mathrm{Ni}, \mathrm{Co}$ and $\mathrm{As}$ in water were significantly exceeded the admissible limit both in summer and winter season. The Buriganga River is considered partially a heavy metal polluted river and the water, sediment and fish are not fully benign for human health and ecosystem [32]. Ahmad and Goni [33] found the mean concentration of $\mathrm{Cu}, \mathrm{Fe}$, and $\mathrm{Cd}$ in irrigation water and $\mathrm{Cd}$ content in soil were much higher than the permissible limit but the metals level were below the allowable limit in vegetables set by the Joint FAO/WHO Expert Committee on Food Additives.

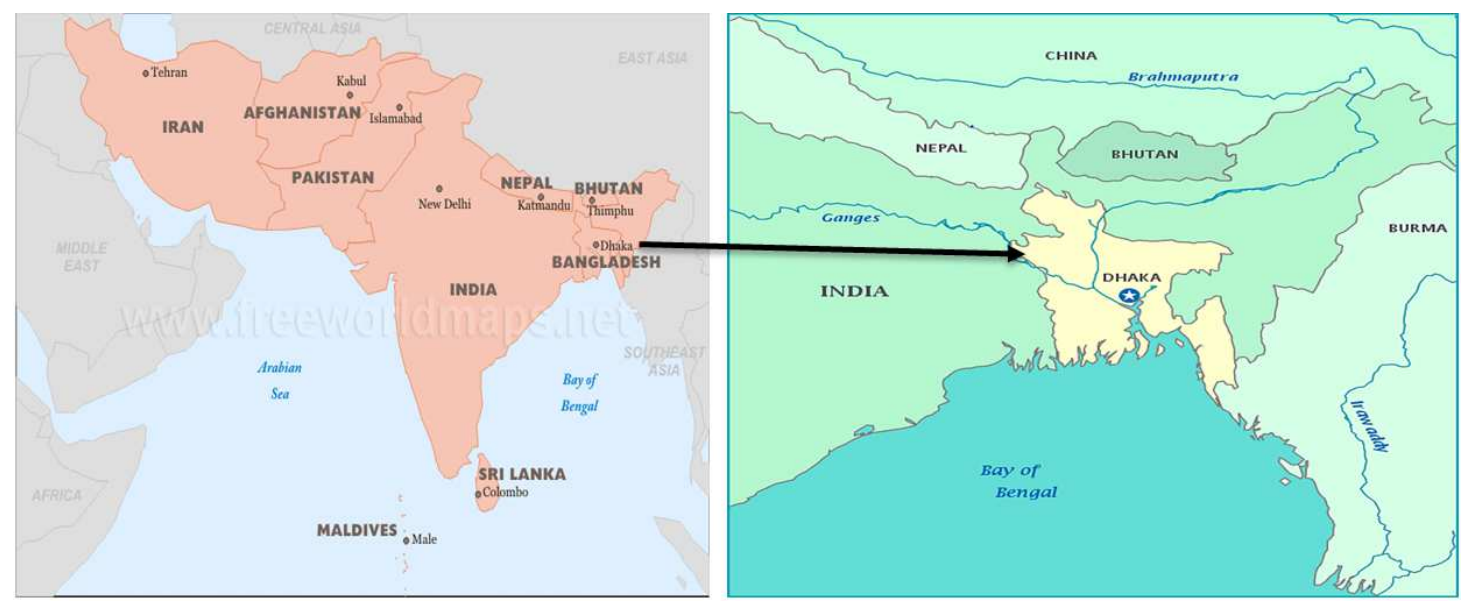

Figure 1. Map showing the study area (Source: Internet)

The Turag River near Dhaka city is being severely polluted by Industrial waste waters and urban sewage from the Tongi municipal and industrial area. The water of this river is pitch black and DO is $0 \mathrm{mg} / 1$ [34]. The major pollution caused by heavy metals. The concentrations of heavy metals in sediment were recorded for $\mathrm{Pb}$ (33.84 \pm 2.899$), \quad \mathrm{Cd}$ (0.36 \pm 0.313$), \mathrm{Cr}(43.98 \pm 19.378), \mathrm{Cu}(53.13 \pm 8.968)$ and $\mathrm{Zn}$ $(53.13 \pm 8.968) \mathrm{mg} / \mathrm{kg}$ dry weight [34]. The metal concentrations in sediments ranged between $\mathrm{Cd}$ : $0.00-0.80$, Cr: 32.00 - 75.50, Cu: 46.30 - 60.00, Pb: 28.30 - 36.40, and Zn: $94.60-190.10 \mathrm{mg} / \mathrm{kg}$ while $\mathrm{Cr}, \mathrm{Cu}, \mathrm{Zn}$ belongs to the category of moderately to highly polluted and $\mathrm{Pb}$ and $\mathrm{Cd}$ belongs to not polluted [35]. The amount of $\mathrm{Mn}, \mathrm{Fe}$ and $\mathrm{Cd}$ exceeded the allowable limit [29] set by WHO [30].

Table 1. Concentration of heavy metals ( $\mathrm{mg} / \mathrm{kg}$ dry weight) of sediments of the Turag River.

\begin{tabular}{llllll}
\hline Location & $(\mathbf{P b})$ & $(\mathbf{C d})$ & $(\mathbf{C r})$ & $(\mathbf{C u})$ & $(\mathbf{Z n )}$ \\
\hline Tongi Bridge & 36.40 & 0.10 & 36.00 & 60.00 & 179.30 \\
World Estema Field & 34.40 & 0.10 & 33.50 & 46.30 & 113.80 \\
Kamarpara Bridge & 30.40 & 0.00 & 75.50 & 46.40 & 190.10 \\
Taltola Bridge & 28.30 & 0.40 & 32.00 & 50.00 & 94.60 \\
Ashulia Beri Bandh & 34.40 & 0.80 & 38.10 & 49.30 & 119.60 \\
Mean & 32.78 & 0.28 & 43.02 & 50.40 & 139.48 \\
Max & 36.40 & 0.80 & 75.50 & 60.00 & 190.10 \\
Min & 28.30 & 0.00 & 32.00 & 46.30 & 94.60 \\
SD & 3.32 & 0.33 & 18.31 & 5.62 & 42.48 \\
\hline
\end{tabular}

Source: [35]

The Karnafully River is the most important and major river of Chittagong that connected with Bay of Bengal [36]. There are many industries close to the river bank without any waste management system [37]. These industries discharge untreated waste in nearest water bodies that finally fall into the Karnafully River. As a result, various refuse and disposable materials come from these industries, ships and oil tankers [37-39]. Ali et al. [40] recorded heavy metals concentrations in water were $13.31-53.87,46.09-112.43,2.54-18.34$ and 5.29-27.45 $\mathrm{g} / \mathrm{L}$ and in sediments were $11.56-35.48,37.23-160.32$, $0.63-3.56$ and $21.98-73.42 \mathrm{mg} / \mathrm{kg}$ for $\mathrm{As}, \mathrm{Cr}, \mathrm{Cd}$ and $\mathrm{Pb}$. This indicate the metal concentrations were above the safe limit for drinking. According to Siddique and Akter [41] the mean concentrations of $\mathrm{Fe}(4.63 \pm 2.035), \mathrm{Pb}$ $(0.25 \pm 0.085)$ and $\mathrm{Cd}(0.03 \pm 0.008) \mu \mathrm{gmL}^{-1}$ were found above the permissible limit in pore water of salt marsh along the Karnafully river coast. Dey et al. [36] mentioned that $\mathrm{Cd}$ exceeded the recommended values and deliberates little sign of presence of metal pollution in the Karnafully River. Islam et al. [42] found higher concentration of $\mathrm{Pb}$ (7.17ppm) in Chapila fish (Gonialosa manmina). 
Table 2. Heavy metal concentration (ppm) of soil, water and fish of the Karnafully River.

\begin{tabular}{llll}
\hline \multirow{2}{*}{ Test Parameters } & Soil & Water & Fish \\
\cline { 2 - 4 } & Conc. \pm SD) & Conc. \pm SD) & Conc. \pm SD) \\
\hline $\mathrm{Pb}$ & $4.96 \pm 0.60$ & $0.14 \pm 0.031$ & $1.67 \pm 0.89$ \\
$\mathrm{Cd}$ & $0.24 \pm 0.02$ & $0.01 \pm 0.002$ & $0.40 \pm 0.25$ \\
$\mathrm{Cu}$ & $1.22 \pm 0.78$ & $0.05 \pm 0.028$ & $1.40 \pm 0.84$ \\
$\mathrm{Mn}$ & $15.30 \pm 72.9$ & $0.12 \pm 0.043$ & $3.77 \pm 2.23$ \\
$\mathrm{Zn}$ & $16.30 \pm 6.82$ & $0.28 \pm 0.139$ & $20.79 \pm 12.4$ \\
$\mathrm{Ag}$ & $0.78 \pm 0.21$ & $0.06 \pm 0.040$ & $0.60 \pm 0.39$ \\
$\mathrm{Cr}$ & $0.76 \pm 0.12$ & $0.25 \pm 0.068$ & $0.45 \pm 0.25$ \\
$\mathrm{Fe}$ & $832.40 \pm 160$ & $2.06 \pm 1.456$ & $69.95 \pm 5.96$ \\
\hline
\end{tabular}

Source: [42]

Table 3. Comparison of water metals with standards.

\begin{tabular}{llll}
\hline $\begin{array}{l}\text { Test } \\
\text { Parameter }\end{array}$ & $\begin{array}{l}\text { Karnofully River } \\
\text { water Metal } \\
\text { (Conc. } \pm \text { SD) } \mathbf{~ p p m}\end{array}$ & $\begin{array}{l}\text { Agricultural use } \\
\text { (NOM-001-ECOL- }\end{array}$ & $\begin{array}{l}\text { For drinking } \\
\text { water (ECR, }\end{array}$ \\
\hline $\mathrm{Pb}$ & $0.14 \pm 0.031$ & 1.0 & $\mathbf{1 9 9 7 )}$ \\
$\mathrm{Cd}$ & $0.01 \pm 0.002$ & 0.4 & 0.05 \\
$\mathrm{Cu}$ & $0.05 \pm 0.028$ & 6.0 & 0.005 \\
$\mathrm{Mn}$ & $0.12 \pm 0.043$ & - & 1 \\
$\mathrm{Zn}$ & $0.28 \pm 0.139$ & 20.0 & 0.1 \\
$\mathrm{Ag}$ & $0.06 \pm 0.040$ & - & 5 \\
$\mathrm{Cr}$ & $0.25 \pm 0.068$ & 1.5 & 0.02 \\
$\mathrm{Fe}$ & $2.06 \pm 1.456$ & - & 0.05 \\
\hline
\end{tabular}

Source: [42]

The Meghna River is also polluted with heavy metals because of rapid urbanization and industrialization. The water, sediment and fishes of the Meghna River contaminated with heavy metals. Heavy metals pollution is now growing concern in developing countries [1]. Rivers play dominant role as pathway for metals transport [2]. According to Bhuyan et al. [43], the concentration of heavy metals varied for $\mathrm{Zn}$ : 8.65-44.48, Al: 1.78-120.4, Cd: BDL0.23, Pb: BDL-6.85, Cu: 0.03-32.44, Ni: BDL-0.986, Fe: 7.85-147.77, Mn: 0.96-20.01, Cr: BDL-8.18, Co: BDL-0.7 $\mathrm{mg} / \mathrm{kg}$ respectively in fish and most of the metals were below the permissible limit set by some international guideline. $\mathrm{Pb}$ and $\mathrm{Zn}$ concentrations were found above the permissible limit in 15 fishes. Hassan et al. [44] reported that the concentrations of $\mathrm{Cd}, \mathrm{Cr}, \mathrm{Mn}$ and $\mathrm{Zn}$ in the Meghna river water are lower but $\mathrm{Fe}$ is higher than standard guidelines. According to USEPA [45] sediment quality guideline, sediment were heavily polluted with $\mathrm{Ni}$.

The Shitalakshyaa River, the second most polluted river in Bangladesh located on the northwestern side of the capital links with the Buriganga River. Majority of the industries and factories are situated on the bank of this river. Due to the geographical location, various metals were found in excess amount. The amount of $\mathrm{Al}, \mathrm{Cd}$ and $\mathrm{Mn}$ exceeded the recommended value set by WHO [30]. The concentrations of $\mathrm{Pb}, \mathrm{Fe}, \mathrm{Cu}$ and $\mathrm{Zn}$ were found below the permissible limit [29]. Rahman et al. [46] reported that the concentrations of heavy metals $(\mathrm{Cd}, \mathrm{Cr}, \mathrm{Ni}, \mathrm{Pb}$ and $\mathrm{Zn})$ are extremely higher than Bangladesh standard for drinking water [47].

The Khiru River located in Mymensingh, mostly polluted by industrial effluents. The concentrations of $\mathrm{Cd}, \mathrm{K}$ and $\mathrm{Na}$ in water were much higher than the permissible limit though the concentrations of $\mathrm{Cu}, \mathrm{Zn}$ and $\mathrm{Pb}$ were recorded below the permissible limit. In case of sediment, the concentrations of metals found within the limit except $\mathrm{Cd}$. In fish muscle, the highest mean accumulation of $\mathrm{Cu}$ (3.65 \pm 1.04$), \mathrm{Zn}$ (106.39 \pm 34.93$), \mathrm{Mn}(27.52 \pm 11.27), \mathrm{Pb}(0.0016 \pm 0.002), \mathrm{Cd}$ $(0.0043 \pm 0.01111), \mathrm{Na}(3746 \pm 2871), \mathrm{K}(41.62 \pm 24.42)$ and As $(0.0008 \pm 0.0009) \mathrm{mg} \mathrm{Kg}{ }^{-1}$ respectively and within the permissible limit [48].

The Rupsha River, another important river of Bangladesh, also polluted by industrial discharge. The water of river endowed with heavy metals. The concentrations of heavy metals in the Rupsha River (passed through Khulna Metropolitan City) water were found within the permissible limits except for $\mathrm{Fe}$ [49]. Khulna city is the $3^{\text {rd }}$ largest industrial city after Dhaka and Chittagong in Bangladesh. Begum et al. [50] mentioned that the average $\mathrm{Fe}$ concentration was recorded $0.30 \pm 0.03 \mathrm{mgL}^{-1}$ in the Rupsha River. Moreover, consumption of fish species from the Rupsha River is expected to exert health hazards for human being as the fishes are also contaminated by heavy metals.

Table 4. Mean concentrations ( \pm SE) of toxic metals in fish muscles including recommended levels provided by [30].

\begin{tabular}{llllllll}
\hline $\begin{array}{l}\text { Metal } \\
\text { mgKg }^{-1}\end{array}$ & $\begin{array}{l}\text { Asian tiger } \\
\text { shrimp }\end{array}$ & $\begin{array}{l}\text { Lesser spiny } \\
\text { eel }\end{array}$ & $\begin{array}{l}\text { Indian river } \\
\text { shad }\end{array}$ & $\begin{array}{l}\text { Spotted } \\
\text { snakehead }\end{array}$ & Tank goby & $\begin{array}{l}\text { Trout barb } \\
\text { levels }\left(\mathbf{m g L} \mathbf{H}^{-\mathbf{1}} \text { ) }\right.\end{array}$ \\
\hline $\mathrm{Cu}$ & $1.054 \pm 0.182$ & $0.126 \pm 0.033$ & $0.133 \pm 0.037$ & $0.134 \pm 0.056$ & $0.124 \pm 0.045$ & $0.102 \pm 0.066$ \\
$\mathrm{Zn}$ & $1.023 \pm 0.211$ & $0.796 \pm 0.230$ & $1.162 \pm 0.173$ & $0.743 \pm 0.245$ & $0.713 \pm 0.134$ & $0.690 \pm 0.034$ \\
$\mathrm{Fe}$ & $2.05 \pm 0.82$ & $1.76 \pm 0.43$ & $2.34 \pm 0.67$ & $2.65 \pm 0.54$ & $3.02 \pm 0.70$ & $1.68 \pm 0.36$ \\
$\mathrm{~Pb}$ & $0.033 \pm 0.019$ & $0.036 \pm 0.014$ & $0.027 \pm 0.013$ & $0.024 \pm 0.009$ & $0.018 \pm 0.015$ & $0.09 \pm 0.016$ & 0.5 \\
$\mathrm{Cr}$ & $0.024 \pm 0.020$ & $0.022 \pm 0.010$ & $0.022 \pm 0.008$ & $0.016 \pm 0.017$ & $0.017 \pm 0.009$ & $0.012 \pm 0.008$ & - \\
$\mathrm{Mn}$ & $0.318 \pm 0.074$ & $0.341 \pm 0.107$ & $0.178 \pm 0.035$ & $0.174 \pm 0.066$ & $0.20 \pm 0.057$ & $0.123 \pm 0.047$ \\
$\mathrm{Ni}$ & $0.054 \pm 0.021$ & $0.028 \pm 0.006$ & $0.037 \pm 0.009$ & $0.035 \pm 0.009$ & $0.024 \pm 0.006$ & $0.024 \pm 0.009$ \\
\hline
\end{tabular}

Source: [49]

The Karnatoli River located near the Dhaka city that heavily polluted by tannery and textiles effluents. The concentration of heavy metals in river water varied due to seasonal changes. The recorded value varied for $\mathrm{Zn}$ : $0.62-$ 68.47, As: 0.56-1.91, Cd: 0.13-1.53, Pb: 0.53-6.8, Ni: 4.2-
8.2, Cr: 2.75-7.0, Cu: 8.6-48.14 $\mu \mathrm{g} / \mathrm{L}$ respectively. Some concentrations exceeded the admissible value [28].

The River Karatoa, the important river of Bangladesh also being contaminated by heavy metals. Zakir et al. [51] stated that the most dominant metals in midstream of the Karatoa 
River was Fe $\left(0.89 \mu \mathrm{g} \mathrm{mL}^{-1}\right)$ and $\mathrm{Mn}\left(0.012 \mu \mathrm{g} \mathrm{mL} \mathrm{m}^{-1}\right)$ among exceeded the surface water quality standard $\left(0.10 \mathrm{mg} \mathrm{L}^{1}\right)$ that 7 metals (Fe, Mn, $\mathrm{Cu}, \mathrm{Zn}, \mathrm{Pb}, \mathrm{Cr}$ and $\mathrm{Ni}$ ). Moreover, $\mathrm{Mn}$ indicates water pollution.

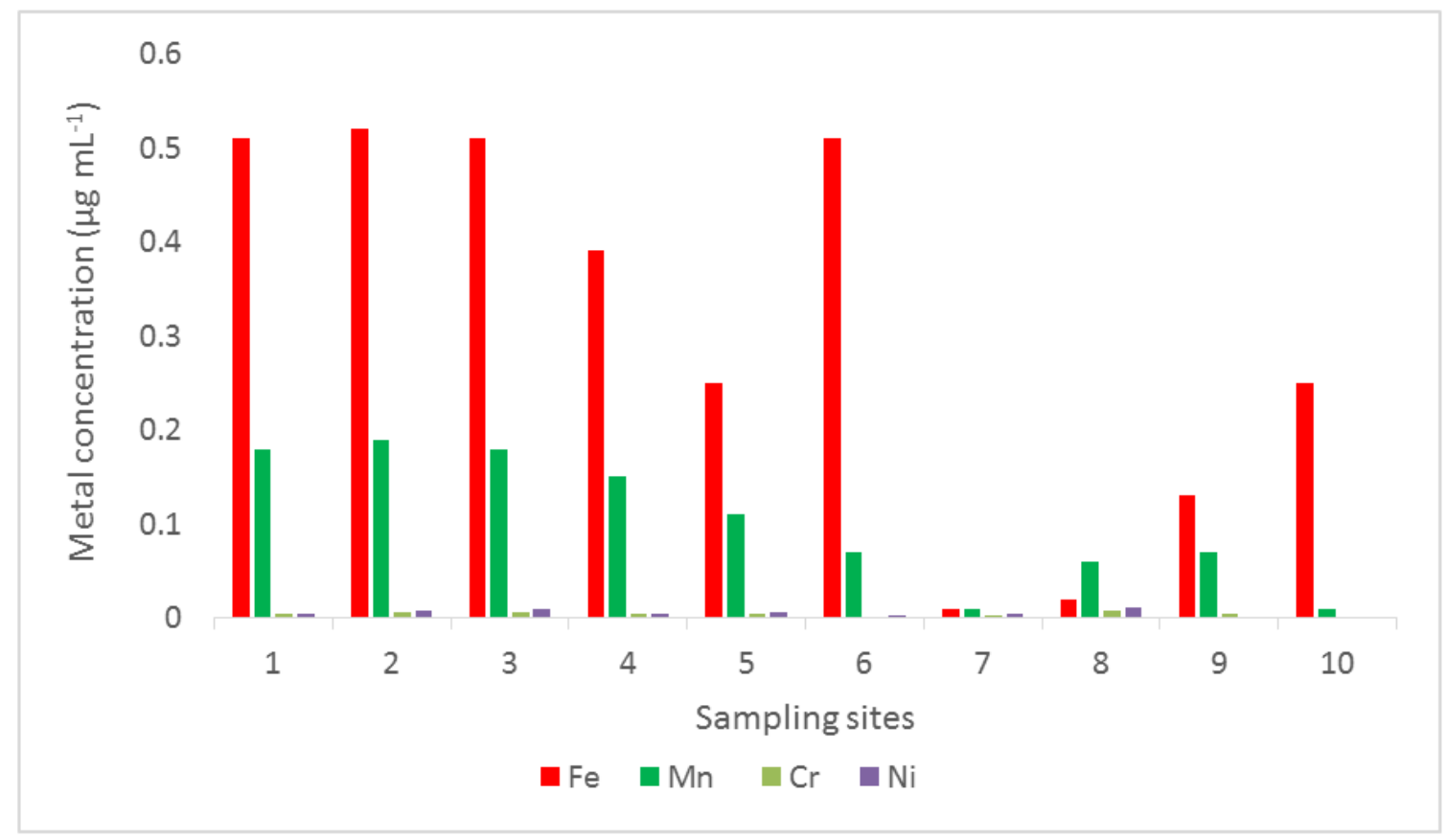

Figure 2. Heavy metals concentrations ( $\mu \mathrm{g} \mathrm{mL}^{-1}$ ) of water collected from midstream of the Karatoa River in Bangladesh [51].

Legend

$1=\mathrm{SP}$ ghat Sewage sludge

$2=$ SP ghat Sewage sludge

$3=$ SP ghat Sewage sludge

$4=$ SP ghat Sewage sludge

$5=$ SP ghat Sewage sludge

$6=$ SP ghat Sewage sludge

$7=$ Bogra Mohila Mohabiddaloy

$8=$ Bogra Mohila Mohabiddaloy

9= Bogra Mohila Mohabiddaloy

$10=$ Bogra Mohila Mohabiddaloy

The Bongshi River located adjacent to capital city and surrounded by many industries. The water of this river continuously being polluted from untreated waste water discharge. According to Sikder et al. [29], the concentrations of $\mathrm{Mn}$ and $\mathrm{Cd}$ exceeded the admissible limit and the value $\mathrm{Al}, \mathrm{Fe}, \mathrm{Cu}$ and $\mathrm{Pb}$ below the permissible limit.

The Balu River close to Dhaka city is also being polluted by industrial inputs and sewage. Discharge of wastewater from various industries without any treatment deteriorate river water quality badly [52-55]. The pollution with heavy metals worsen the situation. Rahman et al. [46] recorded the concentrations of $\mathrm{Cd}$ (0.011), $\mathrm{Cr}$ (0.020), Ni (0.02), $\mathrm{Pb}$ (0.009) and $\mathrm{Zn}(0.86)$ and found that the concentrations of all metals higher than Bangladesh standard for drinking water [47].

The Dhaleshwari River at Rajfulbaria in Savar, Dhaka is being polluted and contaminated by toxic metals. The major contributory factor that contributing heavy metals are industries adjacent to the river. The water and fishes of this river are contaminated with heavy metals that make these resources unsuitable for human consumption as the value of metals exceeded the standard limit. The concentrations of metals in S. aor were Cr: $1.458 \mathrm{mg} / \mathrm{kg}, \mathrm{Cu}: 31.500 \mathrm{mg} / \mathrm{kg}$, $\mathrm{Pb}$ : $18.776 \mathrm{mg} / \mathrm{kg}$ and $\mathrm{Cd}: 0.487 \mathrm{mg} / \mathrm{kg}$ of dry weight; in sediments were $\mathrm{Cr}: 27.393 \mathrm{mg} / \mathrm{kg}, \mathrm{Cu}: 37.450 \mathrm{mg} / \mathrm{kg}, \mathrm{Pb}$ : $15.797 \mathrm{mg} / \mathrm{kg}$ and $\mathrm{Cd}: 2.083 \mathrm{mg} / \mathrm{kg}$, and in water were $\mathrm{Cr}$ : 0.130 ppm, $\mathrm{Cu}: 0.000$ ppm, $\mathrm{Pb}: 0.201 \mathrm{ppm}$ and $\mathrm{Cd}: 0.001$ ppm. The level of concentrations in fish, water and sediment exceeded the FAO approved standard levels [27].

\subsection{Heavy Metal Pollution of City Area}

Dhaka the capital of Bangladesh. In present world, heavy metal accumulation in the soils is a concern of matter because of its potential health risks and detrimental effects on soil ecosystems [56-57]. Some heavy metals required for human and plants at certain level but excessive concentrations can be toxic [57-58] due to its nonbiodegradable nature [59]. Saha and Hossain [31] reported that the amount of $\mathrm{Cr}, \mathrm{Pb}$ and $\mathrm{Pb}$ were found higher than recommended sediment quality guideline stated by USEPA but concentrations in the sludge were found below the limit provided by USEPA for land application of sludge. 
Table 5. Present Status of the Heavy Metals Concentration in Sludge Samples Collected from 10 Different Canals of Dhaka City Area.

\begin{tabular}{|c|c|c|c|c|c|c|c|}
\hline \multirow[t]{2}{*}{ Sl. No. } & \multirow[t]{2}{*}{ Canal's name and (sampling location) } & \multicolumn{6}{|c|}{ Heavy metals concentration (mg/kg) } \\
\hline & & $\mathbf{C d}$ & $\mathbf{C r}$ & $\mathbf{C u}$ & Mn & $\mathbf{P b}$ & $\mathbf{F e}$ \\
\hline 1 & Hazaribagh Khal (Sikder Medical) & 0.3 & 61.8 & 3.8 & 0.72 & 1.9 & 0.11 \\
\hline 2 & Kalyanpur 'Kha' khal (Navana CNG pump) & BDL & 70.6 & 6.6 & 1.6 & 11.1 & 0.22 \\
\hline 3 & Kalyanpur main khal (Darussalam) & 0.1 & 48.6 & 2.8 & 0.63 & 0.1 & 0.09 \\
\hline 4 & Section-2 Digun khal (Rupnagar) & 0.1 & 45.2 & 2.6 & 0.67 & 0.2 & 0.08 \\
\hline 5 & Baunia khal (Section-13) & 0.2 & 117 & 5.4 & 0.51 & 0.1 & 0.08 \\
\hline 6 & Kalyanpur Shakha 'Gha (Shewrapara) & $\mathrm{BDL}$ & 191 & 6.2 & 0.79 & 2.7 & 0.06 \\
\hline 7 & Mohakhali Khal ( Near Bus Stand) & 0.4 & 72.4 & 116 & 0.62 & 51.1 & 0.15 \\
\hline 8 & Mirpur Housing Khal (Mirpur-10) & 0.2 & 48.8 & 187 & 0.23 & 69.1 & 0.07 \\
\hline 9 & Segunbagicha Khal (Kamalapur Stadium) & 0 & 78.6 & 166 & 1.51 & 24.9 & 0.22 \\
\hline 10 & Jirani Khal (Kadamtola) & 0.2 & 75.4 & 304 & 0.66 & 37.3 & 0.06 \\
\hline
\end{tabular}

Source: [31]

The road transports mainly contribute in polluting nearer soils by pollutant transfer through the atmospheric fallouts [60-61] or road runoff [60-62]. Most of the researchers mentioned that the impact of the traffic load on heavy metal contents in top soils and their inconsistency with distance [63-68]. The highest concentrations for lead was recorded in soil $(0.1931 \mathrm{ppm})$ and in plants $(0.1358 \mathrm{ppm})$ for highway on road at $0 \mathrm{~m}$ distance. Contrariwise, the highest concentrations of lead was found in soil $(0.0967 \mathrm{ppm})$ and in plants $(0.0652$ $\mathrm{ppm})$ for railway on road at $0 \mathrm{~m}$ distance. In both cases, the amount exceeded the recommended value set by WHO [63]. The maximum concentrations of heavy metals were recorded in both soil and grasses in the traffic congested area [69]. According to Naser et al. [70], there were prevalent differences in the concentrations of lead, cadmium and nickel for different plant species and soils at various distances and found in the order of nickel $>$ lead $>$ cadmium. Anthropogenic inputs and upward trends of industrial growth considered as the regulatory factors of environmental pollution. Heavy metal enriched in road dust directly related to industrial growth and upward trends of vehicle density in the street. According to Rakib et al. [71], most of the heavy metals $(\mathrm{Pb}$, $\mathrm{Cr}, \mathrm{Zn}$ and $\mathrm{Cu}$ ) were observed to be higher compared to the recommended values. The metal concentrations ranged for Fe: 1.422 to $3.979, \mathrm{Al}: 0.213-1.089$, Ca: $0.489-3.484, \mathrm{~K}$ : 1.496-2.372, Ti: $1.287-3.870$, Mn: $2.200-14.588$, Zr: $5.938-$ 56.750, Sr: 0.980-3.500, Rb: 2.321-4.857, Zn: 2.737-6.526, Sn: 16.667-27.333, P: $3.157-16.286$ and Ba: 0.741 to 3.328 in the surface soil of different locations of Dhaka Aricha highway [72].

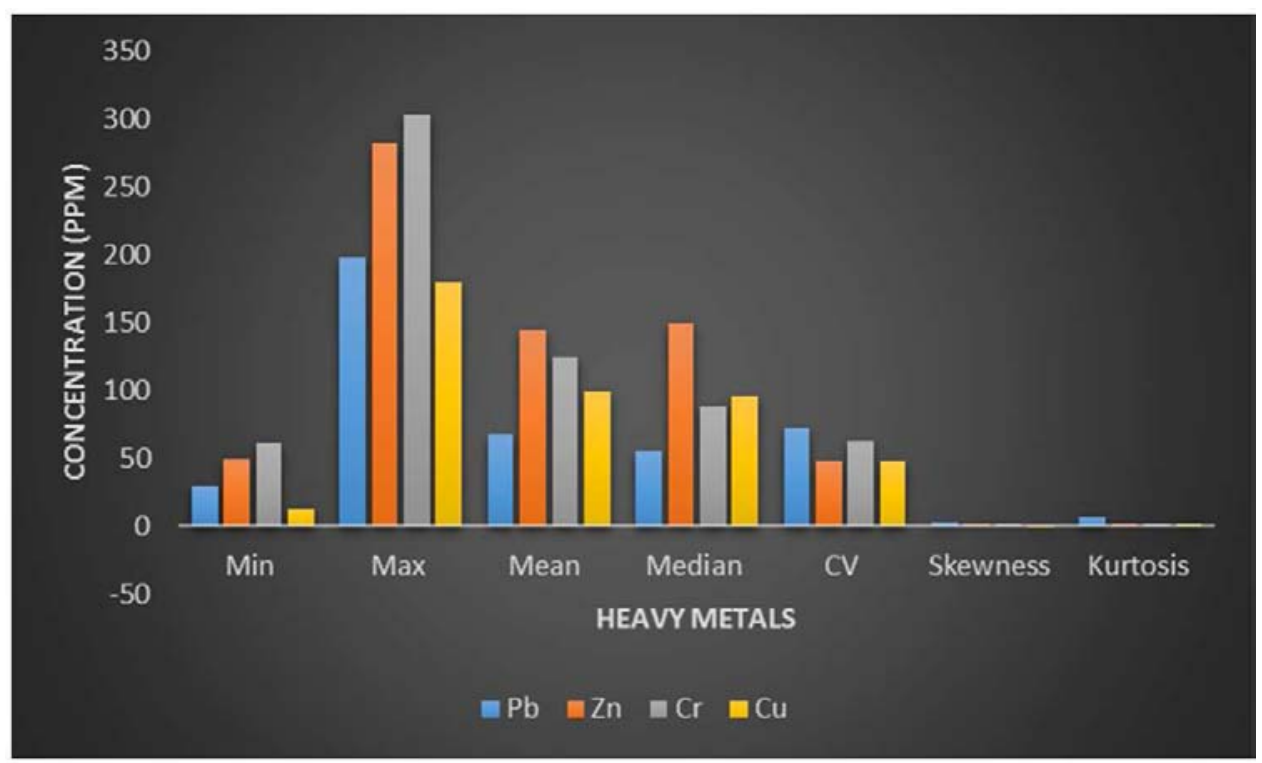

Figure 3. Descriptive statistics of heavy metal concentrations (ppm) in Dhaka Metropolitan City (Source: [71]).

Kushtia, the fastest-growing industrial areas of Bangladesh. There are two regions (BSIC industrial area and Gorai river flowing through Kumarkhali Upazilla) where the main industries are set up. The main cause of pollution in this area is untreated discharge of industrial effluents because of the treatment cost, unconsciousness and other various causes [73-76]. As a result, this effluents may contain considerable amounts of potentially harmful elements and heavy metals like $\mathrm{Fe}, \mathrm{Cu}, \mathrm{Zn}, \mathrm{Mn}, \mathrm{Cd}, \mathrm{Cr}, \mathrm{Pb}$ etc. [77]. Islam et al. [78] reported that the concentration of $\mathrm{Mn}(0.68$ to $0.72 \mathrm{ppm})$ exceeded the drinking water standards, even though $\mathrm{Pb}$ and $\mathrm{Cu}$ were recorded within the standard limit ( 0.0045 to 0.0085 and 1.33 to $1.58 \mathrm{ppm}$ ). 
Table 6. The heavy metal concentrations in water samples of Kushtia industrial zone and comparison with water quality guidelines (in ppm).

\begin{tabular}{lllllll}
\hline Station & Pd & Cd & Cr & Cu & Mn & References \\
\hline BSIC industrial area, Kushtia (mean) & 0.0085 & BDL & BDL & 1.58 & 0.68 & This study \\
Kumarkhali textile area (mean) & 0.0045 & BDL & BDL & 1.33 & 0.72 & This study \\
Bangladesh drinking water standards & 0.05 & 0.005 & 0.05 & 1.0 & 0.10 & {$[48]$} \\
World Health Organization & 0.01 & 0.003 & 0.05 & 2.0 & 0.50 & {$[79]$} \\
Background concentration world average & 0.0002 & 0.00002 & NG & 0.001 & 0.006 & {$[80]$} \\
\hline
\end{tabular}

Source: [78]

Konabari industrial area located on the bank of the Turag River, Gazipur. There are many industries that discharge untreated wastes through the canal. The concentrations of toxic metals in wastewater and sediments of the industrial canals are much higher than that of the river water and sediments. In some case, the concentrations exceeded the permissible limit in sediment [81].

Savar, located just near the capital city that comprises of many isolated water bodies connected or not connected to the river system. The Bansi-Daleshwari and Turag, together form the drainage network of the Savar. The major part of this area are used for industrial activity. For this, the water and sediment adjacent to this area are highly polluted. Faisal et al. [82] showed that the average concentrations of $\mathrm{Mn}, \mathrm{Zn}$, $\mathrm{Cr}$, $\mathrm{Co}$ and $\mathrm{Cu}$ were 584.68, 213.04, 190.33, 164.63 and $100.18 \mathrm{mg} / \mathrm{kg}$ respectively in topsoil. This values were noted above the permissible limit and this is the indication of environmental pollution. Aktaruzzaman et al. [83] recorded higher concentrations of $\mathrm{Cd}(1.00 \pm 0.68) \mathrm{mg} / \mathrm{kg}$ and $\mathrm{Cr}$ $(2.32 \pm 0.84) \mathrm{mg} / \mathrm{kg}$ in the leafy vegetables.

Bhaluka industrial area in Mymensingh was infested with various textiles and garment industries. Textile industries soils contain high levels of lead than in textile effluents in Bangladesh [84]. The value of $\mathrm{Cu}(0.0405 \mathrm{ppm})$ and $\mathrm{Pb}$ $(0.0003 \mathrm{ppm})$ were found lower than recommended level for industrial wastewater. Highest concentrations recorded for $\mathrm{Zn}$ (0.2-1.0 ppm) and lowest amount documented for $\mathrm{Cr}, \mathrm{Cd}$ and $\mathrm{Ni}$ indicated that the river water is suitable for irrigation and aquaculture [85].

Bogra city is highly prone to environmental pollution because of its over population, rapid industrialization and urbanization. The pollution in soil with heavy metals may cause substantial changes in the composition of soil microbial community, badly affecting soil characteristics [8687]. The average $\mathrm{Cd}$ and $\mathrm{Cu}$ concentrations in soil were higher than the recommended value [88].

Table 7. Average heavy metal concentrations $\left(\mu \mathrm{g} \mathrm{g}^{-1}\right)$ in the collected soil samples of different areas of Bogra city, Bangladesh compared with other industrial areas of the world.

\begin{tabular}{|c|c|c|c|c|c|c|c|c|}
\hline $\begin{array}{l}\text { Heavy } \\
\text { metals }\end{array}$ & $\begin{array}{l}\text { Sialkot, } \\
\text { Pakistan }\end{array}$ & $\begin{array}{l}\text { Fuyang } \\
\text { County China }\end{array}$ & $\begin{array}{l}\text { Shiraz industrial } \\
\text { complex zone, Iran }\end{array}$ & $\begin{array}{l}\text { Uttar } \\
\text { Pradesh, } \\
\text { India } \\
\end{array}$ & $\begin{array}{l}\text { Dhaka } \\
\text { City Area }\end{array}$ & $\begin{array}{l}\text { Industrial Sites } \\
\text { of Gazipur }\end{array}$ & $\begin{array}{l}\text { Geochemical } \\
\text { background } \\
\text { (continental crust) }\end{array}$ & $\begin{array}{l}\text { Present } \\
\text { study }\end{array}$ \\
\hline $\mathrm{Cu}$ & 26.85 & 40.77 & 29.87 & 42.90 & 75.04 & 36.18 & 55.00 & 131.87 \\
\hline $\mathrm{Pb}$ & 121.4 & 40.59 & 15.72 & 38.30 & 3.84 & 27.94 & 75.00 & 9.60 \\
\hline $\mathrm{Ni}$ & 85.46 & 21.92 & 154.00 & nd & nd & nd & 12.50 & 7.56 \\
\hline $\mathrm{Cr}$ & 155.0 & nd & nd & 2652.3 & 32.25 & 29.20 & 100.0 & 4.05 \\
\hline Ref & [89] & [90] & [91] & [92] & [93] & [94] & [95] & \\
\hline
\end{tabular}

Source: [88]

Shambhuganj Gouripur is an upazilla under Mymensingh district endowed with many fresh water aquaculture ponds that contribute heavy metals. Heavy metals being intrinsic and natural elements can be toxic at low concentration [96], which mainly originating from fertilizers, animal manures, sewage sludge, agrochemicals and wastewater irrigation [9798]. Sarker et al. [99] reported that the highest concentrations of $\mathrm{Zn}$ and $\mathrm{Ni}$ were found above the recommended value set by the US Environmental Protection Agency's [100] guideline in all sediment samples indicating severely polluted. Moreover, $\mathrm{Cr}$ falls under the moderately polluted range whereas $\mathrm{Pb}$ and $\mathrm{Cd}$ were recorded below the regulated level as per USEPA. In aquaculture farms, most of the fish feed contain maximum concentrations of $\mathrm{Pb}(8.57)$ and $\mathrm{As}$ $(0.909) \mathrm{mg} / \mathrm{kg}$ though $\mathrm{Hg}$ and $\mathrm{Cd}$ concentrations were found to be low [101].
Chittagong the second largest city (port city) of Bangladesh. This city is highly polluted by industries, municipal wastes, two-stroke and diesel-run vehicles. Moreover, being a port city it is also polluted through spillage of ships and mechanized trawler. The concentrations of heavy metals in sediment recorded for $\mathrm{Cd}, \mathrm{Pb}, \mathrm{Cu}, \mathrm{Mn}$ and $\mathrm{Zn}$ were in the range 0.5-1.9, 54-86, 25-50, 261-624 and 204-330 mg kg-1 respectively, indicate contamination of soil with heavy metals [102]. Besides sediment, air of the city also polluted by heavy metals. Ahmed et al. [103] reported that the concentrations of heavy metals in ambient air of different locations in Chittagong city exceeded the threshold limit. Parvin et al. [104] recorded higher concentration of $\mathrm{Pb}$ and $\mathrm{Cr}$ in vegetables (Green arum leaves, jute leaves, water spinach, bottle gourd, wax gourd and sweet gourd collected from industrial area (Nasirabad, Agrabad, Vatiary and Chalkbazar). 
Table 8. Comparison of trace metal concentrations of Chittagong city with other cities.

\begin{tabular}{llllll}
\hline \multirow{2}{*}{ City } & \multicolumn{2}{l}{ Trace metal concentration $(\boldsymbol{\mu g} \mathbf{g} \mathbf{m})$} & & \\
\cline { 2 - 6 } & $\mathbf{C u}$ & $\mathbf{M n}$ & $\mathbf{P b}$ & $\mathbf{C d}$ & References \\
\hline Beijing, China & - & 1.210 & 0.046 & 0.075 & {$[105]$} \\
Islamabad, Pakistan & - & 0.059 & 0.214 & 0.015 & {$[106]$} \\
Vienna, Austria & 0.013 & - & 0.025 & - & {$[107]$} \\
Tehran, Iran & - & 0.078 & 1.020 & 1.12 & {$[108]$} \\
City & Current study & & & & \\
New market & 3.95 & 0.696 & 0.42 & 0.018 & \\
Bahaddarhat & 2.20 & 0.951 & 0.745 & 0.025 & \\
Nasirabad & 4.99 & 1.10 & 0.30 & 0.017 & \\
G. E. C. Circle & 14.48 & 0.54 & 0.16 & 0.017 & \\
Director's office & 12.69 & 0.74 & 0.55 & 0.021 & \\
\hline
\end{tabular}

Source: [103]

\subsection{Heavy Metal Pollution of Coastal Area}

Ship breaking area in Chittagong is highly affected by heavy metal. The sediment samples were moderately to heavily polluted with $\mathrm{Pb}, \mathrm{Cu}, \mathrm{Zn}$ and $\mathrm{Cr}$ but the concentrations in water were found below the permissible limit except $\mathrm{Cr}(0.511 \pm$ $0.284) \mathrm{mg} / \mathrm{l}[83]$.

Table 9. Trace Metals concentrations of sediment at both the affected and control site of Ship breaking area.

\begin{tabular}{|c|c|c|c|c|c|c|c|c|c|c|}
\hline \multirow{6}{*}{ Affected sites } & \multirow{2}{*}{ Stations } & \multicolumn{9}{|c|}{ Heavy Metal Concentration } \\
\hline & & $\mathrm{Fe}(\mu \mathrm{g} / \mathrm{g})$ & Mn $(\mu \mathrm{g} / \mathrm{g})$ & $\mathrm{Cr}(\mu \mathrm{g} / \mathrm{g})$ & $\mathrm{Ni}(\mu \mathrm{g} / \mathrm{g})$ & $\mathrm{Zn}(\boldsymbol{\mu g} / \mathrm{g})$ & $\mathrm{Pb}(\mu \mathrm{g} / \mathrm{g})$ & $\mathrm{Cu}(\mu \mathrm{g} / \mathrm{g})$ & $\mathrm{Cd}(\mu \mathrm{g} / \mathrm{g})$ & $\mathrm{Hg}(\mu \mathrm{g} / \mathrm{g})$ \\
\hline & Salimpur & 11932.6 & 2.64 & 68.35 & 23.12 & 83.78 & 36.78 & 21.05 & 0.57 & 0.015 \\
\hline & Bhatiari & 35216.35 & 8.25 & 86.72 & 35.12 & 102.05 & 122.03 & 39.85 & 0.83 & 0.02 \\
\hline & Sonaichhari & 41361.71 & 6.89 & 78.36 & 48.96 & 142.85 & 147.83 & 30.67 & 0.94 & 0.117 \\
\hline & Kumira & 20971.86 & 2.32 & 22.89 & 25.36 & 119.86 & 41.57 & 28.01 & 0.59 & 0.05 \\
\hline Control site & Sandwip & 3393.37 & 1.8 & 19 & 3.98 & 22.22 & 8.82 & 2.05 & 0.19 & 0.02 \\
\hline
\end{tabular}

Source: [109]

Bay of Bengal coast's sediment (Matamuhuri, Moheshkhali, Bakhkhali, Naf Rivers and St. Martin's Island) was highly polluted with heavy metals that originated mainly from domestic and industrial discharges, gas production plant [110], agriculture and shrimp farming. Heavy metals are being found in water though some preventive actions being applied [111-113]. The heavy metal concentrations in the marine surface water mostly exceed the criteria of international marine water quality [110]. Higher concentrations of $\mathrm{Cd}(.07)$ and $\mathrm{Pb}(0.75) \mu \mathrm{g} / \mathrm{g}$ were recorded from Bay of Bengal coast that exceeded the Environmental Quality Standards of Bangladesh (Cd: 0.05 and $0.10 \mu \mathrm{g} / \mathrm{g}$ ) though $\mathrm{Zn}, \mathrm{Cu}, \mathrm{Mn}$ and $\mathrm{Fe}$ concentrations were recorded within admissible limit [114].

Table 10. Comparisons between average concentrations of heavy metal (ppm) in Bay of Bengal and the standard concentrations of heavy metals in sea water at $3.5 \%$ salinity. ppm $=$ parts per million.

\begin{tabular}{lll}
\hline Name of elements & Average con. of heavy metal $\mathbf{( p p m ) ~ i n ~ p r e s e n t ~ s t u d y ~}$ & $\begin{array}{l}\text { Standard concentration of heavy metal in sea water at 3.5\% } \\
\text { salinity (ppm = parts per million) }\end{array}$ \\
\hline $\mathrm{Pb}$ & 0.0908 & 0.0000300 \\
$\mathrm{Cu}$ & 0.0026 & 0.0009000 \\
$\mathrm{Cd}$ & 0.00214 & 0.0001100 \\
$\mathrm{Cr}$ & 0.00012 & 0.0002000 \\
$\mathrm{Fe}$ & 0.41399 & 0.0034000 \\
$\mathrm{Ni}$ & 0.0000 & 0.0066000 \\
$\mathrm{Ca}$ & 2.33595 & 411 \\
$\mathrm{Mg}$ & 1.122693 & 1290 \\
$\mathrm{Zn}$ & $\mathrm{BDL}$ & 0.0050000 \\
\hline
\end{tabular}

Source: [115]

Sundarbans, the largest, richest (biologically) and most widespread mangrove forest in the biosphere. It is popularly known as world heritage site. Heritiera fomes (3.5 million), ecologically dominant and economically valuable tree species in Sundarbans arena. But unfortunately, millions of the trees and people in Sundarbans are being affected by heavy metal contamination [116]. According to Chaffey et al. [117], 45.2 million of Sundri trees have been affected in Sundarbans.

\subsection{Effects on Aquatic Animals and Human}

The metal pollution of aquatic ecosystems is increasing due to the rapid and unplanned urbanization and 
industrialization [118-122]. Heavy metals are very harmful for aquatic animals [123] and human health [124] due to their toxicity, long-term persistence, and subsequent accumulation [123]. As a result, water, sediment and fish are not fully safe for human health and ecosystem.

Fish are important part of the human diet that have been severely polluted with heavy metals in recent time. Heavy metals pollution destroy the fresh water aquatic ecosystem especially ruined diversified fish community which contributes an important share in the domestic protein demand of the country [125]. Fish and crayfish are used as bio indicators of metal pollution due to their assistance in understanding of the risk to the aquatic ecosystems and to humans [126-128].

Table 11. The effects of toxic metals on marine Biota.

\begin{tabular}{lll}
\hline Pollutants & Organisms & Effects \\
\hline & Fish & At $1 \mu \mathrm{g}$-cd/1 earlier hatching occurs \\
& Increase mortality \\
& Reduction body defence system \\
& Coelenterates & At $1 \mu \mathrm{g}$-cd/1 ctenophores loss growth and survivality Irregular cell division \\
& At $5 \mu \mathrm{g}$-cd/1 Crassorstrea virginia gets slightly delayed development Delayed the maturation system \\
& & Increase mortality and delay \\
Heavy metals & development [129] \\
& Crustaceans & Effects occurs on the shell development \\
& & Irregular cell division \\
& Mortality increase \\
& Reduction body defence \\
& Sea birds & Retardation of growth \\
& Loss of breeding capacity \\
& Reduction of shell thickness of eggs \\
& Irregular structure \\
& Acute toxic condition at the bottom \\
& Retardation of growth \\
\hline
\end{tabular}

Source: [109]

Fishermen and adjacent local people are suffering from various diseases like irritation and skin disease [34]. Moreover, in human body heavy metals can disrupt function in heart, brain, kidneys, bone and liver. Heavy metals (Pb) reduced cognitive development and intellectual performance in children, increased blood pressure and cardio vascular disease in adults [130]. High concentrations of metals can cause cancer of the lung and nasal cavity [131].

Table 12. Negative effects associated with heavy-metal exposure and toxicity.

\begin{tabular}{|c|c|c|c|}
\hline Metal & Acute toxicity & Chronic toxicity & Reference (s) \\
\hline Arsenic & $\begin{array}{l}\text { Bloody urine, GI discomfort, diarrhea, headaches, } \\
\text { vomiting, convulsions, coma, and death }\end{array}$ & $\begin{array}{l}\text { Skin lesions, blisters, Blackfoot disease; organ } \\
\text { failure/damage; diabetes; cancer and mutagenic properties }\end{array}$ & {$[132-135]$} \\
\hline Cadmium & Hepatic, pulmonary, and testicular injury & $\begin{array}{l}\text { Renal and bone injury (osteoporosis); carcinoma (primarily } \\
\text { prostate and renal); toxicity to other organs }\end{array}$ & {$[136-138]$} \\
\hline Chromium & $\begin{array}{l}\text { Vomiting and diarrhea; hemorrhage and blood loss in GI } \\
\text { Tract }\end{array}$ & $\begin{array}{l}\text { Liver/kidney necrosis; skin ulcers, "chrome holes," irritative } \\
\text { dermatitis; ulceration and perforation of the nasal septum; } \\
\text { nasal, pharyngeal, and gastrointestinal carcinomas }\end{array}$ & {$[139-140]$} \\
\hline Lead & $\begin{array}{l}\text { Neurobehavioral problems: impulsivity, distractibility, and } \\
\text { short attention span; mild fatigue; headaches, nausea, } \\
\text { vomiting }\end{array}$ & $\begin{array}{l}\text { Antisocial behaviors; impaired hemoglobin synthesis; } \\
\text { impaired renal function; deafness, blindness, retardation; } \\
\text { decreased IQ, memory loss; decreased libido, fatigue }\end{array}$ & {$[141-145]$} \\
\hline Mercury & $\begin{array}{l}\text { Impaired neurodevelopment; loss of IQ; decrease in } \\
\text { memory, attention, language, and visual-spatial perception } \\
\text { tests; associations with autism and ALS }\end{array}$ & $\begin{array}{l}\text { Impaired neurodevelopment; loss of IQ; decrease in memory, } \\
\text { attention, language, and visual-spatial perception tests; } \\
\text { associations with autism and ALS }\end{array}$ & {$[146-150]$} \\
\hline
\end{tabular}

Source: [151]

Plants the primary producer can absorb heavy metals from soil [152-153] and these metals contaminate the soil [154]. Excessive concentrations of heavy metals in sediment can affect growth of plants by disrupting metabolic functions, physiological and biochemical processes, inhibition of photosynthesis, respiration and degeneration of main cell organelles, even leading to premature death of plants [155]. Though some metal play role as micronutrients in plants [156] but they can be toxic at high concentrations [157] which compelled plants to produce reactive oxygen species that damage plants cell [158]. Ultimately, metals enter into human body in the form of vegetables and cause death [159]. Nabuloa et al. [62] recorded that leaves of roadside crops can amass trace metals at high concentrations, causing a serious health risk to consumers and poisonous to animals grazing on the plants [160]. Plants, prolonged exposure to heavy metals leads to cellular damage and disturbance of cellular ionic homeostasis. Top-dying of Heritiera fomes (Sundri) in Sundarbans directly linked with Exchangeable Sn, K, Pb, Sr and $\mathrm{Zn} \mathrm{[161].}$ 


\section{Conclusion}

From the findings of the present review, it is evident that water, aquatic organisms and roadside dust are being polluted increasingly. Being long persistent metals in nature these substances exacerbating the health problems both in human being and fish. As a consequence, different fatal and chronic diseases find their permanent residency in living organisms through the process of biomagnification. Above study proved that, industrial area are adversely affected by heavy metals rather than non-industrial area. For the meaningful and sustainable development of the country industrial growth needed badly but this development should be environment friendly. Industries should not discharge their effluents directly to the river water rather they must use Effluent Treatment Plant (ETP).

\section{References}

[1] Silambarasan, K., Senthilkumaar, V and Velmurugan, K (2012) Studies on the distribution of heavy metal concentrations in river Adyar, Chennai, Tamil Nadu. Eur. J. Exp. Biol., 2: 2192-2198.

[2] Mohiuddin, K. M., Zakir, H. M., Otomo, K., Sharmin, S and Shikazono N (2010) Geochemical distribution of trace metal pollutants in water and sediments of downstream of an urban river. International Journal of Environmental Science \& Technology, 7: 17-28. DOI: 10.1007/BF03326113.

[3] UNFPA, United Nations Populations Founds (2011) Retrieved from offonce/home/news/pid/7204; jsessionid $=6$ C355D2E24817C8362750097E42535EB. (Verified March 3, 2011).

[4] Sobsey, M. D., Stauber, C. E., Casanova, L. M., Brown, J. M and Elliott, M. A (2008) Point of use household drinking water filtration: A practical, affective solution for proving sustained access to safe drinking water in the developing world. Environ Sci Technol. 42: 4261-4267.

[5] Lugoli, F., Leopizzi, M. I., Bagordo, F., Grassi, T., Guido, M and De Donno, A (2011) Widespread microbiological groundwater contamination in the South-eastern Salenco (Puglia-Italy). J Environ Monit. 13: 192-200. DOI: 10.1039/c0em00193g.

[6] Akter, A. and Ali, M. H (2011) Arsenic contamination in groundwater and its proposed remedial measures. Int. J. Environ. Sci. Tech. 8: 433-443.

[7] Bruzzoniti, M. C., Fungi, M and Sarzanini, C (2010) Determination of EPA's priority pollutant polycyclic aromatic hydrocarbons in drinking waters by solid phase extractionHPLC. Analytical Methods, 2: 739-745. DOI: 10.1039/B9AY00203K.

[8] Wu, B., Zhang, Y., Zhang, X. X and Cheng, S. P (2010) Health risk from exposure of organic pollutants through drinking water consumption in Nanjing, China. Bulletin of Environmental Contamination and Toxicology, 84: 46-50. DOI: $10.1007 / \mathrm{s} 00128-009-9900-8$.

[9] Manassaram, D. M., Backer, L. C., Messing, R., Fleming, L. E., Luke, B and Monteilh, C. P (2010) Nitrates in drinking water and methemoglobin levels in pregnancy: a longitudinal study. Environmental Health. 9: 60. DOI: 10.1186/1476069X-9-60.

[10] Bourdineaud, J. P (2010) Heavy metals toxicity at very low, yet environmentally relevant doses: the cases of human mercurial contaminations through fish consumption, uranium in drinking water, and gold nanoparticles in aquatic systems. Comparative Biochemistry and Physiology, Part A, 157: S35S35. 10.1016/j.cbpa.2010.06.099.

[11] Vashishat, N and Kler, T. K (2014) Birds as Bioindicators of Heavy Metal Pollution, AGROLOOK, 1-6.

[12] Kabata-Pendias, Alina, Mukherjee, Arun, B. (2007) Trace elements from soil to human. Environmental Toxicology, New York: Springer-Verlag. ISBN 978-3-540-32714-1.

[13] Garza, A., Vega, R and Soto, E (2005) Cellular and molecular mechanism of lead neurotoxicity. Med Sci Monit. 28: 48-58.

[14] Bouchard, M. F., Sauve, S., Barbeau, B., Legrand, M., Brodeur, M. E., Bouffard, T., Limoges, E., Bellinger, D. C., Mergler, D (2011) Intellectual impairment in school-age children exposed to manganese from drinking water. Environ Health Perspect. 119: 138-143. doi: 10.1289/ehp.1002321.

[15] Holmstrup, M., Sorensen, J. G., Overgaard, J., Bayley, M., Bindesbol, A. M., Slotsbo, S., Fisker, K. V., Maraldo, K., Waagner, D., Labouriau, R and Asmund, G (2011) Body metal concentrations and glycogen reserves in earthworms (Dendrobaena octaedra) from contaminated and uncontaminated forest soil. Environmental Pollution, 159: 190-197. http://dx.doi.org/10.1016/j.envpol.2010.09.005.

[16] Jomova, K., Jenisova, Z., Feszterova, M., Baros, S., Liska, J., Hudecova, D., Rhodes, C. J and Valko, M (2011) Arsenic: toxicity, oxidative stress and human disease. J Appl Toxicol. 31: $95-107$. DOI: $10.1002 /$ jat.1649.

[17] Salgado-Bustamante, M., Ortiz-Perez, M. D., CalderonAranda, E., EstradaCapetillo, L., Nino-Moreno, P., GonzalezAmaro, R and Portales-Perez, D (2010) Pattern of expression of apoptosis and inflammatory genes in humans exposed to arsenic and/or fluoride. Sci Total Environ. 408: 760-767. DOI: 10.1016/j.scitotenv.2009.11.016.

[18] Burger, J., Campbell, K. R., Murray, S., Campbell, T. S., Gaines, K. F., Jeitner, C., Shukla, T., Burke, S., Gochfeld, M (2007) Metal level in blood, muscle and liver of water snales (Nerodia spp.) from New Jersey, Tennessee and South Carolina. Science of The Total Environment, 373: 556-563. http://dx.doi.org/10.1016/j.scitotenv.2006.06.018.

[19] Visnjic-Jeftic, Z., Jaric, I., Jovanovic, L., Skoric, S., Smederevac-Lalic, M., Nikcevic, M and Lenhardt, M (2010) Heavy metal and trace element accumulation in muscle, liver and gills of the Pontic shad (Alosa immaculate Bennet 1835) from the Danube River (Serbia). Microchem. J. 95: 341-344.

[20] DiGioacchino, M., Petrarca, C., Perrone, A., Farina, M., Sabbioni, E., Hartung, T., Martino, S., Esposito, D. L., Lotti, L. V and Mariani-Costantini, R (2008) Autophagy as an ultrastructural marker of heavy metal toxicity in human cord blood hematopoietic stem cells. Sci Total Environ. 392: 50-58. DOI: $10.1016 /$ j.scitotenv.2007.11.009.

[21] Thomas, S., Glahn, F and Foth, H (2009) Effects of heavy metals and tobacco smoke condensate on the glutathione-level in cultured human lung cells. Toxicol Lett. 189: S224-S225. DOI: $10.1016 /$ j.toxlet.2009.06.526. 
[22] Johri, N., Jacquillet, G and Unwin, R (2010) Heavy metal poisoning: the effects of cadmium on the kidney. BioMetals, 23: 783-792. DOI: 10.1007/s10534-010-9328-y.

[23] Otles, S and Cagindi, O (2010) Health importance of arsenic in drinking water and food. Environ Geochem Health. 32: 367-371. DOI: 10.1007/s10653-010-9296-8.

[24] http://www.mapsofworld.com/bangladesh/bangladeshlocation-map.html.

[25] Mohiuddin, K. M., Ogawa, Y., Zakir, H. M., Otomo, K., Shikazono, N (2011) Heavy metals contamination in water and sediments of an urban river in a developing country, International Journal of Environmental Science \& Technology, 8: 723-736. DOI: 10.1007/BF03326257.

[26] Bhuiyan, M. A. H., Dampare, S. B., Islam, M. A and Suzuki, S (2014) Source apportionment and pollution evaluation of heavy metals in water and sediments of Buriganga River, Bangladesh, using multivariate analysis and pollution evaluation indices, Environmental Monitoring and Assessment, 187: 40-75, DOI: 10.1007/s10661-014-4075-0.

[27] Ahmed, A. T. B., Mandal, S., Chowdhury, D. A., Rayhan, M. A., Tareq and Rahman, M (2012) Bioaccumulation of some heavy metals in Ayre fish (Sperata aor Hamilton, 1822), Sediment and water of Dhaleshwari River in dry season, Bangladesh J. Zool. 40: 147-153.

[28] Das, M., Ahmed, M. K., Islam, M. S., Islam, M. M and Akter, M. S (2011) Heavy metals in industrial effluents (Tannery and Textile) and adjacent rivers of Dhaka city, Bangladesh, Terrestrial and Aquatic Environmental Toxicology.

[29] Sikder, M. T., Kihara, Y., Yasuda, M., Yustiawati and Mihara, Y (2013) River water pollution in developed and developing countries: Judge and assessment of physicochemical characteristics and selected dissolved metal concentration. Clean Soil Air Water, 41: 60-68. DOI: 10.1002/clen.201100320.

[30] WHO (World Health Organization) (2011) Guidelines for drinking water quality-1, recommendations. World Health Organization, Geneva, 4th edition.

[31] Saha, P. K and Hossain M. D (2011) Assessment of Heavy Metal Contamination and Sediment Quality in the Buriganga River, Bangladesh, International Conference on Environmental Science and Technology IPCBEE vol. 6 (2011) (C) (2011) IACSIT Press, Singapore.

[32] Ahmad, M. K., Islam, S., Rahman, S., Haque, M. R and Islam, M. M (2010) Heavy Metals in Water, Sediment and Some Fishes of Buriganga River, Bangladesh, International Journal of Environmental Research, 4: 321-332.

[33] Ahmad, J. and Goni, M (2010) Heavy metal contamination in water, soil, and vegetables of the industrial areas in Dhaka, Bangladesh, Environmental Monitoring \& Assessment, 166: 347.

[34] Sikder, M. N. A., Huq, S. M. S., Mamun, M. A. A., Hoque, K. M., Bhuyan, M. S and Abu Bakar, M. A (2016) Assessment of physicochemical parameters with its effects on human and aquatic animals giving special preference to effective management of Turag River, IOSR Journal of Environmental Science, Toxicology and Food Technology, 10: 41-51.

[35] Banu, Z., Chowdhury, M. S. A., Hossain, M. D., Nakagami, K (2013) Contamination and Ecological Risk Assessment of Heavy Metal in the Sediment of Turag River, Bangladesh: An Index Analysis Approach, Earth \& Environmental Sciences, 5:
239-248 DOI: 10.4236/jwarp.2013.52024.

[36] Dey, S., Das, J and Manchur, M. A (2015) Studies on Heavy Metal Pollution of Karnaphuli River, Chittagong, Bangladesh, IOSR Journal of Environmental Science, Toxicology and Food Technology, 9: 79-83.

[37] Das, B., Y. S. A., Khan and Sarker, M. A. K (2002) Trace metal concentration in water of the Karnafully river estuary of the Bay of Bengal. Pakistan Journal of Biological Sciences, 5: 607-608. DOI: 10.3923/pjbs.2002.607.608.

[38] Khan, M. A. A and Khan, Y. S. A (2003) Trace metals in littoral sediments from the north east coast of the Bay of Bengal along the ship breaking area, Chittagong, Bangladesh. Journal of Biological Sciences, 3: 1050-1057. DOI: 10.3923/jbs.2003.1050.1057.

[39] Ogbo, E. M. and Okhuoya, J. A (2011) Bioavailability of some heavy metals in crude oil contaminated soils remediated with Pleurotus tuber-regium. Fr. Singer. Asian Journal of Biological Sciences, 4: 53-61. DOI: 10.3923/ajbs.2011.53.61.

[40] Ali, M. M., Ali, M. L., Islam, M. I., Rahman, M. Z (2016) Preliminary assessment of heavy metals in water and sediment of Karnaphuli River, Bangladesh, Environmental Nanotechnology, Monitoring \& Management, 5: 27-35. http://dx.doi.org/10.1016/j.enmm.2016.01.002.

[41] Siddique, M. A. M and Akter, M (2012) Heavy metal concentration in pore water of salt marsh along the Karnafully river coast, Bangladesh, Journal of Environmental Science and Technology, 5: 241-248. DOI: 10.3923/jest.2012.241.248.

[42] Islam, F., Rahman, M., Khan, S. S. A., Ahmed, B., Bakar, A And Halder, M (2013) Heavy Metals in Water, Sediment and some Fishes of Karnofuly River, Bangladesh, Poll Res. 32: 715-721.

[43] Bhuyan, M. S., Islam, M. S., Bakar, M. A., Akhtar, A (2016) Heavy metals status in some commercially important fishes of Meghna River adjacent to Narsingdi District, Bangladesh: Health risk assessment, American Journal of Life Sciences. 4: 60-70. doi: 10.11648/j.ajls.20160402.17.

[44] Hassan, M., Mirza, A. T. M., Rahman, T., Saha, B and Kamal, A. K. I (2015) Status of Heavy Metals in Water and Sediment of the Meghna River, Bangladesh, American Journal of Environmental Sciences, 11: 427.439, DOI: 10.3844/ajessp.2015.427.439 .

[45] USEPA (1989) Sediment classification methods compendium. Draft Final Report, United States Environmental Protection Agency, Watershed Protection Division, USA.

[46] Rahman, S., Khan, M. T. R., Akib, S and Biswas, S. K (2012) Investigation of Heavy Metal Pollution in Peripheral River Water around Dhaka City, Pensee Journal, 75: 421-433.

[47] ECR (Environment Conservation Rules) (1997) Government of the People's Republic of Bangladesh, Ministry of Environment and Forest, Bangladesh.

[48] Rashid, H., Hasan, M. N., Tanu, M. B., Parveen, R., Sukhan, Z. P., Rahman, M. S and Mahmud, Y (2012) Heavy Metal Pollution and Chemical Profile of Khiru River, Bangladesh, International Journal of Environment, 2: 57-63.

[49] Samad, M. A., Mahmud, Y., Adhikary, R. K., Rahman, S. B. M., Haq, M. S and Rashid, H (2015) Chemical Profile and Heavy Metal Concentration in Water and Freshwater Species of Rupsha River, Bangladesh. American Journal of Environmental Protection, 3: 180-186. doi: 10.12691/env-3-6-1. 
[50] Begum, S., Ikejima, K., Ara, H. and Islam, M. Z (2006) Alternative Processing Option from Shrimp Processing Biowaste in Khulna District-Southwestern part of Bangladesh. Journal of Applied Sciences, 6: 1307-1313. DOI: 10.3923/jas.2006.1307.1313.

[51] Zakir, H. M., Moshfiqur, R. M., Rahman, A., Ahmed, I and Hossain, M. A (2012) Heavy Metals and Major Ionic Pollution Assessment in Waters of Midstream of the River Karatoa in Bangladesh, Journal of Environmental Science and Natural Resources, 5: $149 \quad$ - $160 . \quad$ DOI: http://dx.doi.org/10.3329/jesnr.v5i2.14806.

[52] Rahman, S and Hossain, F (2007) Spatial Assessment of Water Quality in Peripheral Rivers of Dhaka City for Optimal Relocation of Water Intake Point. Water Resources Management, 1: 377-391. DOI: 10.1007/s11269-007-9167-y.

[53] Subramanian, B (2004) Water quality in South Asia. Asian Journal Water Environment Pollution, 1: 41-54.

[54] Karn, S. K and Harada, H (2001) Surface water pollution in three urban territories of Nepal, India, and Bangladesh. Environmental Management, 28: 483-496. DOI $10.1007 / \mathrm{s} 002670010238$.

[55] Kamal, M. M., Malmgren-Hansen, A and Badruzzaman, A. B. M (1999) Assessment of pollution of the River Buriganga, Bangladesh, using a water quality model. Water Science and Technology, 40: 129-136. doi: 10.1016/S0273-1223 (99)00474-6.

[56] McLaughlin, M. J., Parker, D. R. and Clarke, J. M (1999) Metals and micronutrients-food safety issues. Field Crops Research, 60: 143-163. http://dx.doi.org/10.1016/S0378-4290 (98)00137-3.

[57] Qishlaqi, A and Farid Moore, F (2007) Statistical Analysis of Accumulation and Sources of Heavy Metals Occurrence in Agricultural Soils of Khoshk River Banks, Shiraz, Iran, American-Eurasian J. Agric. \& Environ. Sci. 2: 565-573.

[58] Bilos, C., Colomb, J. C. Skorupka, C. N. and Rodriguez, P. M. J (2001) Sources, distribution and variability of air borne trace metals in La Plata city are, Argentina. Environmental Pollution, 11: 149-158. http://dx.doi.org/10.1016/S0269-7491 (99)00328-0.

[59] Facchinelli, A., E., Sacchi and Mallen, L (2001) Multivariate statistical and GIS-based approach to identify heavy metals sources in soils. Environmental Pollution, 114: 313-324. http://dx.doi.org/10.1016/S0269-7491 (00)00243-8.

[60] Viard, B., Pihan, F., Promeyrat, S and Pihan, J. C (2004) Integrated assessment of heavy metal $(\mathrm{Pb}, \mathrm{Zn}, \mathrm{Cd})$ highway pollution: bioaccumulation in soil, Graminaceae and land snails. Chemosphere, 55: 1349-1359. DOI: 10.1016/j.chemosphere.2004.01.003.

[61] Nabuloa, G., Oryem-Origa, H and Diamond, M (2006) Assessment of lead, cadmium, and zinc contamination of roadside soils, surface films, and vegetables in Kampala City, Uganda. Environmental Research, 101: 42-52. http://dx.doi.org/10.1016/j.envres.2005.12.016.

[62] Mitsch, W. J and Gosselink, J. G (1993) Wetlands, 2nd edn. Van Nostrand- Reinhold, USA.

[63] Bhowmick, A. C., Khan, M. M. R., Moim, M. I., Bhoumik, N. C., Saifullah, A. S. M (2015) Comparative Study of Heavy Lead Pollution in Roadside Soil and Plants by Railway and Highway at Tangail District in Bangladesh, Universal Journal of Applied Science, 3: 21-25. DOI:

10.13189/ujas.2015.030301.

[64] Ward, N., Brooks, R. R., Roberts, E and Boswell, C. R (1977) Heavy metal pollution from automotive emissions and its effect on roadside soils and pasture species in New Zealand. Environ Sci Technol. 11: 917-920. DOI: 10.1021/es60132a007.

[65] Rodríguez-Flores, M and Rodríguez-Castellón, E (1982) Lead and cadmium levels in soils and plants near highways and their correlations with traffic density. Environmental Pollution Series B, Chemical and Physical, 4: 281-290. doi: 10.1016/0143-148X (82)90014-3.

[66] Garcia, R and Millan, E (1998) Assessment of Cd, Pb and Zn contamination in roadside soils and grasses from Gipuzkoa (Spain). Chemosphere, 37: 1615-1625. doi: 10.1016/S00456535 (98)00152-0.

[67] Zhang, H., Ma, D., Xie, Q and Chen, X (1999) An approach to studying heavy metal pollution caused by modern city development in Nanjing, China. Environmental Geology, 38: 223 -228. doi: 10.1007/s002540050418.

[68] Turer, D. G and Maynard, B. J (2003) Heavy metal contamination in highway soils. Comparison of Corpus Christi, Texas and Cincinnati. Clean Technologies and Environmental Policy, 4: 235-245. DOI: 10.1007/s10098-0020159-6.

[69] Uddin, Shihab; Parvin, Shahnaj; Sultana, Nahida; Hossain, Z. M (2014) Heavy Metal Accumulation in Roadside Soils and Grasses of Dhaka City, Bangladesh, Journal of Agricultural Science, 6: 176. DOI: http://dx.doi.org/10.5539/jas.v6n3p176.

[70] Naser, H. M., Gomes, S. S. R and Shamsun Noor, S (2012) Heavy metal pollution of soil and vegetable grown near roadside at Gazipur, Bangladesh Journal of Agricultural Research, 37: 9-17. DOI: http://dx.doi.org/10.3329/bjar.v37i1.11170.

[71] Rakib, M. A., Ali, M., Akter, M. S and Mohammad Bhuiyan, A. H (2014) Assessment of Heavy Metal (Pb, Zn, Cr and Cu) Content in Roadside Dust of Dhaka Metropolitan City, Bangladesh, International Research Journal of Environment Sciences, 3: 1-5.

[72] Ahmed, M. K., Shaheen, N., Islam, M. S., Al-Mamun, M. H., Islam, S., Islam, M. M., Kundu, G. K. and Bhattacharjee, L (2016) A comprehensive assessment of arsenic in commonly consumed foodstuffs to evaluate the potential health risk in Bangladesh. Science of The Total Environment, 544: 125133. http://dx.doi.org/10.1016/j.scitotenv.2015.11.133.

[73] Valipour, M (2015a) A comprehensive study on irrigation management in Asia and Oceania. Archives of Agronomy and Soil Science, 61: 1247-1271. http://dx.doi.org/10.1080/03650340.2014.986471.

[74] Valipour, M (2015b) Assessment of Important Factors for water Resources Management in European Agriculture. J. Water Res. Hydra. Eng. 4: 171-180.

[75] Shaktibala, T and Bhagat, S. K (2012) Characterization of Waste Water of Industrial area of Sitapura, Jaipur for Post Monsoon Season 2012. Int. J. Sci. Res. Rev. 2: 227-235.

[76] Ladwani, K. D., Ladwani, K. D., Manik, V. S and Ramteke, D. S (2012) Impact of Industrial Effluent Discharge on PhysicoChemical Characteristics of Agricultural Soil. International Research Journal of Environment Sciences, 1: 32-36. 
[77] Ram, S., Lokhande, Pravin, U. S and Deepali, S. P (2011) Study on PhysicoChemical Water Parameters of Waste Effluents from Taloja Industrial Area of Mumbai, India. International Journal of Ecosystem, 1: 1-9. doi: 10.5923/j.ije.20110101.01.

[78] Islam, M. S., Ahmed, M. K., Raknuzzaman, M., HabibullahAl-Mamun, M and Islam, M. K (2015) Heavy metal pollution in surface water and sediment: a preliminary assessment of an urban river in a developing country. Ecological Indicators, 48: 282-291. 10.1016/j.ecolind.2014.08.016.

[79] WHO (World Health Organization) (1993) Guidelines for Drinking Water Quality, Vol. 1, $2^{\text {nd }}$ ed., Geneva.

[80] Klavins, M, Briede, A., Rodinov, V., Kokorite, I., Parele, E and Klavina, I (2000) Heavy metals in rivers of Latvia. Science of The Total Environment, 262: 175-183. http://dx.doi.org/10.1016/S0048-9697 (00)00597-0.

[81] Sultana, S. M., Kulsum, U., Shakila, A and Islam, M. S (2012) Toxic Metal Contamination on the River near Industrial Area of Dhaka, Available Online at: www.environmentaljournal.org. 2: 56-64.

[82] Faisal, B. M. R., Majumder, R. K., Uddin, M. J., Deeba, F., Paul, D., Haydar, M. A., Ali, M. I (2015) Assessment of heavy metals pollution and natural radioactivity in topsoil of Savar industrial area, Bangladesh, International Journal of Environmental Sciences, 5: 964-979. DOI: 10.6088/ijes.2014050100091.

[83] Aktaruzzaman, M., Chowdhury, M. A. Z., Fardous, Z., Alam, M. K., Hossain, M. S and Fakhruddin, A. N. M (2014) Ecological Risk Posed by Heavy Metals Contamination of Ship Breaking Yards in Bangladesh, Int. J. Environ. Res. 8: 469-478.

[84] Kabir, E., Ray, S., Kim, K. H., Yoon, H., Jeon, E., Kim, Y. S., Cho, Y. S., Yun, S. T and Brown, R. J. C (2012) Current Status of Trace Metal Pollution in Soils Affected by Industrial Activities, Scientific World Journal. 2012: 1-18, doi: 10.1100/2012/916705.

[85] Sarker, B. C, Baten, M. A., Haque, M. E., Das, A. K., Hossain, A and Hasan, M. Z (2015) Heavy Metals' Concentration in Textile and Garments Industries' Wastewater of Bhaluka Industrial Area, Mymensingh, Bangladesh, Current World Environment, 10: 61-66. http://dx.doi.org/10.12944/CWE.10.1.07.

[86] Kurek, E and Bollag, J. M (2004) Microbial immobilization of cadmium released from $\mathrm{CdO}$ in the soil. Biogeochemistry, 69: 227-239. 10.1023/B: BIOG.0000031046.40036.df.

[87] Giller, K. E., Witter, E and McGrath, S. P (1998) Toxicity of heavy metals to microorganism and microbial processes in agricultural soils: A review. Soil Biology and Biochemistry, 30: 1389-1414. http://dx.doi.org/10.1016/S0038-0717 (97)00270-8.

[88] Begum, K., Mohiuddin, K. M., Zakir, H. M., Rahman, M. M., Hasan, M. N (2014) Heavy Metal Pollution and Major Nutrient Elements Assessment in the Soils of Bogra City in Bangladesh, Canadian Chemical Transactions, 2: 316-326, DOI: 10.13179/canchemtrans.2014.02.03.0088.

[89] Malik, R. N., Jadoon, W. A and Husain, S. Z (2010) Metal contamination of surface soils of industrial city Sailkot, Pakistan: a multivariate and GIS approach. Environmental
Geochemistry and Health, 32: 179-191. DOI: 10.1007/s10653-009-9274-1.

[90] Zhang, X. Y., Lin, F. F., Wong, M. T. F., Feng, X. L and Wang, $\mathrm{K}$ (2009) Identification of soil heavy metal sources from anthropogenic activities and pollution assessment of Fuyang County, China. Environmental Monitoring and Assessment, 154: 439-449. doi: 10.1007/s10661-008-0410-7.

[91] Shakeri, A., Moore F and Modabberi, S (2009) Heavy metal contamination and distribution in the Shiraz industrial complex zone soil, South Shiraz, Iran. World Applied Sciences Journal, 6: 413-425.

[92] Gowd, S. S., Reddy, M. R., Govil, P. K (2010) Assessment of heavy metal contamination in soils at Jajmau (Kanpur) and Unnao industrial areas of the Ganga Plain, Uttar Pradesh, India. Journal of Hazardous Materials, 174: 113-121. http://dx.doi.org/10.1016/j.jhazmat.2009.09.024.

[93] Sultana, N (2010) Nutrition content and heavy metal contamination in some roadside soils and grasses of Dhaka City, Bangladesh. M. S. Thesis, Department of Agricultural Chemistry, Bangladesh Agricultural University, Mymensingh, 2010.

[94] Sumi, S. S (2010) Toxic metallic contamination in industrial wastewater and soils of some selected areas of Gazipur, Bangladesh. M. S. Thesis, Department of Agricultural Chemistry, Bangladesh Agricultural University, Mymensingh 2010.

[95] Taylor, S. R (1964) Abundances of chemical elements in the continental crust: a new table. Geochimicaet Cosmochimica Acta, 28: 1273-1285. doi: 10.1016/0016-7037 (64)90129-2.

[96] Lenntech (2004) Water Treatment and Air Purification. Water Treatment, Published by Lenntech, Rotterdamseweg, Netherlands.

[97] Zhang, M. K., Liu, Z. Y and Wang, H (2010) Use of single extraction methods to predict bioavailability of heavy metals in polluted soils to rice, Communications in Soil Science and Plant Analysis, 41: 820-883. http://dx.doi.org/10.1080/00103621003592341.

[98] Khan, S., Cao, Q., Zheng, Y. M., Huang, Y. Z and Zhu, Y. G (2008) Health risks of heavymetals in contaminated soils and food crops irrigated with wastewater inBeijing, China, Environmental Pollution, 152: 686-692.

http://dx.doi.org/10.1016/j.envpol.2007.06.056.

[99] Sarker, J M., Kanungo, I., Tanmay, M. H and Patwary, S. A. M (2016) A Study on the Determination of Heavy Metals in Sediment of Fish Farms in Bangladesh. Fish Aquac J, 7: 159. doi: 10.4172/2150-3508.1000159.

[100] USEPA (1991) Sediment quality guidelines. Draft report. EPA Region V Chicago IL.

[101] Shamshad, B. Q., Shahidur, R. K and Tasrena, R. C (2009) Studies on toxic elements accumulation in shrimp from fish feed used in Bangladesh, Asian Journal of Food and AgroIndustry, 2: 440-444.

[102] Alam, S. S., Osman, K. T., Kibria, M. G (2011) Heavy metal pollution of soil from industrial and municipal wastes in Chittagong, Bangladesh, Archives of Agronomy and Soil Science, 58: 1427-1438. http://dx.doi.org/10.1080/03650340.2011.596826. 
[103] Ahmed, M. J., Ali, M. K., Hossain, M., Siraj, S., Ahsan, M. A (2012) Determination of trace metals in air of Chittagong cityBangladesh, European Journal of Chemistry, 3: 416-420. DOI: 10.5155/eurjchem.3.4.416-420.645.

[104] Parvin, R., Sultana, A and Zahid, M. A (2014) Detection of Heavy Metals in Vegetables Cultivated In Different Locations in Chittagong, Bangladesh, IOSR Journal of Environmental Science, Toxicology and Food Technology, 8: 58-63.

[105] Mori, I. M., Nishikawa, T. T and Quan, H (2003) Atmos. Environ. 37: 4263-4268

[106] Shaheen, N., Shah, M. H. and Jaffar, M (2005) A Study of Airborne Selected Metals and Particle Size Distribution in Relation to Climatic Variables and Their Source Identification. Water, Air, and Soil Pollution, 164, 275-294. http://dx.doi.org/10.1007/s11270-005-3542-1.

[107] Rostami, S., Sohrabpour, M., Mirzaee, H and Puxbaun, T (1999) Environ. Int. 25: 969-981.

[108] Sohrabpour, M., Mirzaee, H., Rostami, S and Athari, M (1999) Elemental concentration of the suspended particulate matter in the air of Tehran, Environment International, 25: 7581. doi: 10.1016/S0160-4120 (98)00088-9.

[109] Siddiquee, N. A., Parween, S., Quddus, M. M. A and Barua, P (2009) Heavy Metal Pollution in Sediments at Ship Breaking Area of Bangladesh, Coastal Environments: Focus on Asian Regions, pp. 78-87. DOI: 10.1007/978-90-481-3002-3_6.

[110] Hasan, M. R., Khan, M. Z. H., Khan, M., Aktar, S., Rahman, M., Hossain, F and Hasan, A. S. M. M (2016) Heavy metals distribution and contamination in surface water of the Bay of Bengal coast, Cogent Environmental Science, http://dx.doi.org/10.1080/23311843.2016.1140001.

[111]Dural, M., and Bickici, E (2010) Distribution of trace elements in the Upeneus pori and Upeneus molucensis from the eastern coast of Mediterranean, Iskenderun bay, Turkey. Journal of Animal and Veterinary Advances, 9: 1380-1383. DOI: 10.3923 javaa.2010.1380.1383

[112] Kumar, B., Rita, S and Mukherjee, D (2011) Geochemical distribution of heavy metals in sediments from sewage fed fish ponds from Kolkata wetlands, India. Chemical Speciation \& Bioavailability, 23: 24-32.

http://dx.doi.org/10.3184/095422911X12966667026105.

[113] Kumar, B., Senthilkumar, K., Priya, M., Mukhopadhyaya, D. $P$ and Saha, R (2010) Distribution, partitioning, bioaccumulation of trace elements in water, sediment and fish from sewage fed fish ponds in eastern Kolkata. India. Toxicological \& Environmental Chemistry, 92: 243-260. http://dx.doi.org/10.1080/02772240902942394.

[114] Ashraful M. A. K., Assim Z., Ismail, N (2009) Monitoring and assessment of heavy metals levels in littoral sediments from the north eastern part of the Bay of Bengal coast, Bangladesh. Journal of Industrial Pollution Control, 25: 105-111.

[115] Rashid, T., Hoque, S and Akter, S (2015) Pollution in the Bay of Bengal: Impact on Marine Ecosystem. Earth \& Environmental Sciences, 5: 55-63. http://dx.doi.org/10.4236/ojms.2015.51006.

[116] Awal, M. A (2007) Analysis of possible environmental factors causing top-dying in mangrove forest trees in the Sundarbans in Bangladesh. PhD thesis, University of Bradford.

[117] Chaffey, D. R., Millar, F. R. and Sandom, J. H (1985) A forest inventory of the Sundarbans, Bangladesh, Main Report. Project Report No. 140, 196pp, Overseas Development Agency, London, U. K., pp. 195-196.

[118] Martin, J. A. R., Arana, C. D., Ramos-Miras, J. J., Gil, C., Boluda, R (2015) Impact of 70 years urban growth associated with heavy metal pollution. Environmental Pollution, 196: 156-163. http://dx.doi.org/10.1016/j.envpol.2014.10.014.

[119] Grigoratos, T., Samara, C., Voutsa, D., Manoli, E., Kouras, A (2014) Chemical composition and mass closure of ambient coarse particle sattraffic and urban background sites inThessaloniki, Greece. Environ Sci Pollut Res Int. 21: 77087722. DOI: 10.1007/s11356-014-2732-z.

[120] Zhang, C., Qiao, Q., Piper, J. D. A and Huang, B (2011) Assessment of heavy metal pollution from a Fe-smelting plant in urban river sediments using environmental magnetic and geochemical methods. Environ Pollut. 159: 3057-3070. DOI: 10.1016/j.envpol.2011.04.006.

[121] Bai, J., Xiao, R., Cui, B., Zhang, K., Wang, Q., Liu, X., Gao, H., Huang, L (2011) Assessment of heavy metal pollution in wetland soils from the young and old reclaimed regions in the Pearl River Estuary, South China. Environmental Pollution, 159: 817-824. http://dx.doi.org/10.1016/j.envpol.2010.11.004.

[122] Sekabira, K., Oryem Origa, H., Basamba, T. A., Mutumba, G., Kakudidi, E (2010) Assessment of heavy metal pollution in the urban stream sediments and its tributaries. International Journal of Environmental Science \& Technology, 7: 435-446. DOI: $10.1007 / \mathrm{BF} 03326153$.

[123] Sin, S., Chua, H., Lo, W and Ng, L. M (2001) Assessment of heavy metal cations in sediments of Shing Mun River, Hong Kong. Environment International, 26: 297-301. http://dx.doi.org/10.1016/S0160-4120 (01)00003-4.

[124] Cook, J. A., Andrew, S. M and Johnson, M. S (1990) Lead, zinc, cadmium and fluoride in small mammals from contaminated grassland established on fluorspar tailings. Water, Air, and Soil Pollution, 51: 43-54. DOI: 10.1007/BF00211502.

[125] Khan, M. K. A (2008) Environmental Pollution around Dhaka EPZ and its Impact on Soil, Water and Ecology, an unpublished M. Sc. thesis, Department of Geology, University of Dhaka.

[126] Lamas, S., Fernández, J. A., Aboal, J. R. and Carballeira, A (2007) Testing the use of juvenile Salmo trutta L. as biomonitors of heavy metal pollution in fresh water. Chemosphere, 67: 221-228.

http://dx.doi.org/10.1016/j.chemosphere.2006.10.040.

[127] Peakall, D and Burger, J (2003) Methodologies for assessing exposure to metals: speciation, bioavibility of metals and ecological host factors. Ecotoxicology and Environmental Safety, 56: 110-121. http://dx.doi.org/10.1016/S0147-6513 (03)00055-1.

[128] Rashed, M. N (2001) Monitoring of environmental heavy metals in fish from Nasser Lake. Environment International, 27: 27-33. http://dx.doi.org/10.1016/S0160-4120 (01)00050-2.

[129] Mirkes, D. Z., Vernberg, W. B and Decoursey, J (1978) Effects of cadmium and mercury on theBehavioural responses and development of Eurypanopeus depressus larvae. Marine Biology, 47: 143-147. DOI: 10.1007/BF00395. 
[130]Commission of the European Communities (2001) Commission Regulation (EC) No. 221/2002 of 6 February 2002 amending regulation (EC) No. 466/2002 setting maximum levels for certain contaminants in foodstuffs. Official Journal of the European Communities, Brussels, 6 February 2002.

[131] USFDA (1993) United States Food and drug administration, Guidance document for chromium in shellfish. DHHS/PHS/FDA/CFSAN/Office of seafood, Washington D. C.

[132] Cebrian, M. E., Albores, A., Aguilar, M and Blakely, E (1983) Chronic arsenic poisoning in the north of Mexico. Hum Toxicol. 2: 121-133.

[133] Hughes, M. F (2002) Arsenic toxicity and potential mechanisms of action. Toxicology Letters. 133: 1-16. http://dx.doi.org/10.1016/S0378-4274 (02)00084-X.

[134] Kenney, L. J and Kaplan, J. H (1988) Arsenate substitutes for phosphate in the human red cell sodium pump and anion exchanger. J Biol Chem. 263: 7954-7960.

[135] Smith, A. H., Lopipero, P. A., Bates, M. N and Steinmaus, C. M (2002) Arsenic epidemiology and drinking water standards. Science, 296: 2145-2146. DOI: 10.1126/science.1072896.

[136] Mishima, A., Yamamoto, C., Fujiwara, Y and Kaji, T (1997) Tolerance to cadmium cytotoxicity is induced by zinc through non-metallothionein mechanisms as well as metallothionein induction in cultured cells. Toxicology. 118: 85-92.

[137] Satarug, S., Garrett, S. H., Sens, M. A and Sens, D. A (2010) Cadmium, environmental exposure, and health outcomes. Environ Health Perspect. 118: 182-190. DOI: 10.1289/ehp.0901234.

[138] Waalkes, M. P and Goering, P. L (1990) Metallothionein and other cadmium-binding proteins: recent developments. Chem. Res. Toxicol. 3: 281-288. DOI: 10.1021/tx00016a001.

[139] Dayan, A. D and Paine, A. J (2001) Mechanisms of chromium toxicity, carcinogenicity and allergenicity: review of the literature from 1985 to 2000. Hum Exp Toxicol. 20: 439-451.

[140] Zhitkovich, A (2011) Chromium in drinking water: sources, metabolism, and cancer risks. Chem Res Toxicol. 24: 16171629. DOI: $10.1021 / \mathrm{tx} 200251 \mathrm{t}$.

[141] Bellinger, D., Leviton, A., Waternaux, C., Needleman, H., Rabinowitz, M (1987) Longitudinal analyses of prenatal and postnatal lead exposure and early cognitive development. N Engl J Med, 316: 1037-1043. DOI: 10.1056/NEJM198704233161701.

[142] Gracia, R. C and Snodgrass, W. R (2007) Lead toxicity and chelation therapy. Am J Health Syst Pharm. 64: 45-53. DOI: 10.2146/ajhp060175.

[143] Moreira, F. R and Moreira, J. C (2004) Effects of lead exposure on the human body and health implications. Rev. Panam. Salud Publica, 15: 119-129.

[144] Canfield, R. L., Henderson, C. R. J., Cory-Slechta, D. A., Cox, C., Jusko, T. A and Lanphear, B. P (2003) Intellectual impairment in children with blood lead concentrations below $10 \mathrm{~g}$ per deciliter. $\mathrm{N}$ Engl J Med. 143: 687- 688. DOI: 10.1056/NEJMoa022848.

[145] Silbergeld, E. K (1991) 'Lead in Bone: Implications for
Toxicology During Pregnancy and Lactation', Environ. Health Perspect. 91: 63-70.

[146] Geier, D. A and Geier, M. R (2007) A prospective study of mercury toxicity biomarkers in autistic spectrum disorders. J. Toxicol. Environ. J Toxicol Environ Health A. 70: 1723-1730. DOI: $10.1080 / 15287390701457712$.

[147] Grandjean, P (1997) Cognitive deficit in 7-year-old children with prenatal exposure to methylmercury. Neurotoxicol Teratol. 19: 417-428.

[148] FAO/WHO Expert Committee on Food Additives (2007) Evaluation of certain food additives and contaminants. World Health Org. Tech. Rep. Ser. 940: 1-92.

[149]Llop, S (2012) Prenatal exposure to mercury and infant neurodevelopment in a multicenter cohort in Spain: study of potential modifiers. Am J Epidemiol. 175: 451-465. DOI: 10.1093/aje/kwr328.

[150] Roos, P. M and Dencker, L (2012) Mercury in the spinal cold after inhalation of mercury. Basic Clin Pharmacol Toxicol. 111: 126-132. DOI: 10.1111/j.1742-7843.2012.00872.x.

[151] Monachese, M., Burton, J. P., Reid, G (2012) Bioremediation and Tolerance of Humans to Heavy Metals through Microbial Processes: a Potential Role for Probiotics, Appl Environ Microbiol., 78: 63-97. DOI: 10.1128/AEM.01665-12.

[152] Kakulu, S. E and Abdullahi, N. K (2004) Impact of municipal solid waste on trace metal concentrations in herbage and soil samples of the Abuja municipality. Global Journal of Environmental $\quad$ Sciences. 3 65-69. http://dx.doi.org/10.4314/gjes.v3i1.2431.

[153] Rajaram, T and Das, A (2008) Water pollution by industrial effluents in India discharge scenarios and case for participatory ecosystem specific local regulation. Futures, 40: 56-69. http://dx.doi.org/10.1016/j.futures.2007.06.002.

[154] Udosen, E. D., Udoessien, E. I and Ibok, U. J (1990) Evaluation of some metals in the industrial wastes from a paint industry and their environmental pollution implications. Nigerian J Technol Res, 2: 71-77.

[155] Agoramoorthy, G., Chen, F. A., Venkatesalu, V and Shea, P. C (2009) Bioconcentration of heavy metals in selected medicinal plants of India. Journal of Environmental Biology, 30: 175178.

[156] Sharma, C. P (2006) Plant Micronutrient. First Edition. Science Publisher, New Hampshier, USA. 2006, 5-10.

[157] Pandey, S. N (2008) Growth and biochemical changes in pulse seedlings irrigated with effluent from electroplating industry. Journal of Applied Biological Science, 34: 79-82.

[158] Gajewska, E., Sklodowska, M., Slaba, M., and Mazur, J (2006) Effect of nickel on oxidative enzyme activities, proline and chlorophyll contents in wheat shoots. Biologia Plantarum, 50: 653-659.

[159] Odiette, W. O (1999) Environmental physiology of animals and pollution diversified Resources Ltd, Lagos, pp 171-85.

[160] Raven, P. H and Evert, R. F (1976) Biology of plants, 2nd edn. Worth Publishers Inc, NewYork, p 544.

[161] Awal, M. A (2014) Analysis of Environmental Pollution in Sundarbans. American Journal of Biomedical and Life Sciences. 2: 98-107. doi: 10.11648/j.ajbls.20140205.11. 